\title{
Cardioprotective effects of exenatide against oxidative stress-induced injury
}

\author{
GUANGLEI CHANG, DONGYING ZHANG, HUI YU, PENG ZHANG, YING WANG, AIHUA ZHENG and SHU QIN
}

Department of Cardiology, The First Affiliated Hospital of Chongqing Medical University, Chongqing 400016, P.R. China

Received May 16,2013; Accepted August 16, 2013

DOI: $10.3892 /$ ijmm.2013.1475

\begin{abstract}
Myocardial ischemia/reperfusion (MI/R) leads to oxidative stress, which may in turn lead to myocardial injury. In the present study, we investigated the effects of exenatide, a glucagon-like peptide-1 (GLP-1) analogue, on oxidative stress-induced injury in vitro and in vivo. In in vitro experiments, $\mathrm{H} 9 \mathrm{c} 2$ cells were incubated with exenatide to determine the direct cytoprotective effects of exenatide following exposure to hydrogen peroxide $\left(\mathrm{H}_{2} \mathrm{O}_{2}\right)$. Pre-treatment with exenatide $(1 \mathrm{nM})$, prior to $\mathrm{H}_{2} \mathrm{O}_{2}$ exposure, increased cell viability and inhibited $\mathrm{H}_{2} \mathrm{O}_{2}$-induced reactive oxygen species (ROS) production. Exenatide also decreased the levels of lactate dehydrogenase $(\mathrm{LDH})$ and creatine kinase-MB (CK-MB) in the cultured supernatants, as well as those of malondialdehyde (MDA) in the $\mathrm{H} 9 \mathrm{c} 2$ cells and increased the total superoxide dismutase (T-SOD) levels in the H9c2 cells. In in vivo experiments, an animal model of MI/R was induced by coronary occlusion. Pre-treatment with exenatide (10 $\mu \mathrm{g} / \mathrm{kg} /$ day) protected the rat hearts from MI/R-induced injury by decreasing the levels of $\mathrm{LDH}$ and CK-MB in plasma, increasing the levels of catalase, T-SOD and glutathione peroxidase (GSH-Px) in the heart and decreasing the MDA levels in the rats with MI/R-induced injury. Exenatide also reduced the infarct size and enhanced cardiac function in the rats with MI/R-induced injury. Moreover, pre-treatment with exenatide inhibited cardiomyocyte apoptosis, increased $\mathrm{Akt}^{\text {serine473 }}$ and Bad $^{\text {serine136 }}$ phosphorylation and decreased cleaved caspase-3 expression in vitro and in vivo; however, these effects were attenuated by the phosphoinositide 3-kinase (PI3K) inhibitor, LY294002. Our results suggest that exenatide exerts significant cardioprotective effects against oxidative stress-induced injury in vitro and in vivo. The mechanisms involved may be attributed to the scavenging of oxidative stress products, such as ROS, the increase in the concentrations of antioxidant
\end{abstract}

Correspondence to: Professor Shu Qin, Department of Cardiology, The First Affiliated Hospital of Chongqing Medical University, 1 Yixueyuan Road, Yuzhong District, Chongqing 400016, P.R. China E-mail: augustlei127@aliyun.com

Key words: glucagon-like peptide-1 analogue, exenatide, ischemia/ reperfusion, oxidative stress-induced injury, cardiomyocyte apoptosis, cardiac function defense enzymes and the inhibition of cardiomyocyte apoptosis. The anti-apoptotic effects of exenatide were, at least in part, associated with the activation of the PI3K/Akt signaling pathway.

\section{Introduction}

Myocardial ischemia/reperfusion (MI/R) injury occurs inevitably in a wide range of patients, such as survivors of cardiac arrest, victims of acute myocardial infarction, as well as in patients undergoing cardiac surgery (1). MI/R leads to oxidative stress, which subsequently leads to reactive oxygen species (ROS) production, an increase in malondialdehyde (MDA) levels and subsequent cytotoxic injury $(2,3)$. Oxidative stress and the accelerated ROS production induced by $\mathrm{MI} / \mathrm{R}$ play key roles in the progression of ischemic heart disease and cardiomyocyte apoptosis (2-4). A number of studies have suggested that cardiomyocyte apoptosis induces a spectrum of events, including cardiac remodeling, a larger infarct size and severe heart failure $(5,6)$. Although cardiomyocyte and tissue damage induced by oxidative stress has been extensively investigated in recent years, there is still a need for effective therapeutic strategies.

Glucagon-like peptide-1 (GLP-1), a gut hormone, has been confirmed to exert potent insulin-releasing and glucose-lowering effects (7). However, its short half-life limits its clinical use. Therefore, analogues of GLP-1 with much longer half-lives, such as exenatide have been developed and are currently being used as novel anti-diabetic drugs $(7,8)$. A large number of studies have demonstrated that GLP-1 and its analogues have multiple beneficial effects on the cardiovascular system (9-12). It has been reported that GLP-1 and its analogues inhibit cardiomyocyte apoptosis by regulating the c-Jun N-terminal protein kinase signaling pathway (13), the phosphoinositide 3-kinase (PI3K) pathway (14), the ERK1/2 pathway (14), as well as others (15). However, to date, to our knowledge, the cardioprotective effects of exenatide on oxidative stress-induced injury have not been investigated in depth.

The aim of this study was to determine whether exenatide is capable of reducing oxidative stress-induced injury. To establish this, we used a model of oxidative stress induced by hydrogen peroxide $\left(\mathrm{H}_{2} \mathrm{O}_{2}\right)$ to assess the effects of exenatide against oxidative stress-induced injury in $\mathrm{H} 9 \mathrm{c} 2$ cells. Furthermore, the rat model of MI/R was used to evaluate the therapeutic efficacy of exenatide against oxidative damage in 
the heart. We also investigated the possible mechanims behind the anti-apoptotic effects of exenatide by assessing the activation of the PI3K/Akt signaling pathway.

\section{Materials and methods}

Cell culture and $\mathrm{H}_{2} \mathrm{O}_{2}$ treatment. The rat cardiomyoblast cell line, H9c2, was purchased from the Cell Culture Center of Institute of Basic Medical Sciences, (Chinese Academy of Medical Sciences). The cells were cultured in Dulbecco's modified Eagle's medium/Ham's Nutrient Mixture F12 (DMEM/F12; Thermo Fisher Biochemical Products Co., Ltd., Beijing, China) supplemented with $10 \%$ fetal bovine serum (FBS; Invitrogen Life Technologies, Carlsbad, CA, USA), penicillin $(100 \mathrm{U} / \mathrm{ml})$ and streptomycin $(10 \mu \mathrm{g} / \mathrm{ml}$; both from Beyotime Institute of Biotechnology, Haimen, China) and incubated at $37^{\circ} \mathrm{C}$ in a humidified atmosphere containing $5 \% \mathrm{CO}_{2}$.

We first aimed to determine the most effective concentration of $\mathrm{H}_{2} \mathrm{O}_{2}$ to establish the model of oxidative stress. The $\mathrm{H} 9 \mathrm{c} 2$ cells were treated with 4 different concentrations $(50,100,200$ and $400 \mu \mathrm{M})$ of $\mathrm{H}_{2} \mathrm{O}_{2}$ for $6 \mathrm{~h}$. We then evaluated the protective effects of exenatide (Baxter Pharmaceutical Solutions LLC, Deerfield, IL, USA). The cells were pre-treated with various concentrations $(0.01,0.1,1$ and $10 \mathrm{nM})$ of exenatide for 30 min prior to exposure to $\mathrm{H}_{2} \mathrm{O}_{2}$. When the most effective concentrations of $\mathrm{H}_{2} \mathrm{O}_{2}$ and exenatide were determined, the cells were randomly assigned to one of the following 4 groups: i) the control group: cells were cultured under normal incubation conditions; ii) the $\mathrm{H}_{2} \mathrm{O}_{2}$ group: cells were exposed to $\mathrm{H}_{2} \mathrm{O}_{2}$ without pre-treatment with exenatide; iii) the exenatide group: cells were pre-treated with exenatide for $30 \mathrm{~min}$ prior to exposure to $\mathrm{H}_{2} \mathrm{O}_{2}$; iv) the exenatide + LY294002 (exenatide $+\mathrm{L}$ ) group: to observe the effects of exenatide on $\mathrm{H} 9 \mathrm{c} 2$ cell apoptosis, the cells were pre-treated with the PI3K inhibitor, LY294002 (15 $\mu$ M; Santa Cruz Biotechnology, Inc., Santa Cruz, CA, USA), for $10 \mathrm{~min}$ prior to exenatide treatment.

Viability assay. Cell viability was assessed using the 3-(4,5-dimethylthiazol-2-yl)-2,5-diphenyltetrazolium bromide cell proliferation and cytotoxicity assay kit (MTT; Beyotime Institute of Biotechnology, Haimen, China) according to the manufacturer's instructions. Briefly, the cells were seeded in a 96-well plate at a density of $1 \times 10^{4}$ cells/well and incubated for $24 \mathrm{~h}$. The cells were then pre-treated with or without exenatide $(0.01,0.1,1$ and $10 \mathrm{nM})$ for 30 min subsequent to incubation with $\mathrm{H}_{2} \mathrm{O}_{2}(50,100,200$ and $400 \mu \mathrm{M})$ for $6 \mathrm{~h}$. The cells were administered with fresh medium and MTT solution (10 $\mu \mathrm{l})$ for $4 \mathrm{~h}$ followed by incubation with formazan solution $(10 \mu \mathrm{l})$ for $4 \mathrm{~h}$ at $37^{\circ} \mathrm{C}$. The optical density (OD) values at $570 \mathrm{~nm}$ were measured using a microplate reader (Multiskan MK33; Thermolab Systems, Helsinki, Finland). Each experiment was repeated 6 times and the data are expressed as a percentage of the control.

Flow cytometry. Cell apoptosis was detected using flow cytometry as previously described with some modifications (16). After the indicated treatments, the cells were collected by centrifugation at $600 \mathrm{xg}$ for $5 \mathrm{~min}$ and resuspended at a density of $1 \times 10^{6}$ cells $/ \mathrm{ml}$. Cells $(500 \mu \mathrm{l})$ were mixed with fluorescein isothiocyanate (FITC)-Annexin $\mathrm{V}(5 \mu \mathrm{l})$ and propidium iodide (PI; $10 \mu \mathrm{l}, 20 \mu \mathrm{g} / \mathrm{ml}$ ) and incubated for $20 \mathrm{~min}$ in the dark at room temperature and analyzed immediately on a flow cytometer. Flow cytometric analysis (excitation $488 \mathrm{~nm} / \mathrm{emis}-$ sion $530 \mathrm{~nm}$ ) was performed on a FACSCalibur cell sorter (BD FACSVantage SE; Beckman Coulter, Brea, CA, USA). Each experiment was repeated 3 times.

In order to quantitatively analyze the production of ROS, we measured ROS levels by flow cytometry as previously described with some modifications (16). After the indicated treatments, the cells were treated with 2',7'-dichlorofluorescein diacetate (DCFH-DA; $1 \mathrm{ml}, 60 \mathrm{~min}$, Beyotime Institute of Biotechnology) at $37^{\circ} \mathrm{C}$. The fluorescence intensity was measured by flow cytometry and analyzed using CellQuest ${ }^{\mathrm{TM}}$ software. The experiment was repeated 3 times and the data are expressed as the mean fluorescence intensity.

Experimental animals. Male Sprague-Dawley rats (6-8 weeks of age) were purchased from the Laboratory Animal Center of Chongqing Medical University, Chongqing, China [certificate: SCXK (YU) 2007-0001]. The rats were housed under optimal conditions for hygiene, temperature, photoperiods (12L:12D) and standard laboratory chow and water were provided ad libitum, conforming to the Guidelines for Care and Use of Laboratory Animals. All procedures on animals were approved by the Ethics Committee of Chongqing Medical University.

Experimental model of MI/R-induced injury. Thirty-two male Sprague-Dawley rats were randomly divided into 4 groups ( $\mathrm{n}=8)$ : i) sham-operated group; ii) MI/R group; iii) exenatide group; and iv) exenatide + LY294002 (exenatide + L) group. To observe the anti-apoptotic effects of exenatide, the animals were pre-treated with the PI3K inhibitor, LY294002, for $30 \mathrm{~min}$ prior to exenatide treatment. Exenatide $(10 \mu \mathrm{g} / \mathrm{kg} / \mathrm{day})$ was administered by intraperitoneal injection for 2 weeks. LY294002 (0.3 mg/kg/3 days) was administered by intraperitoneal injection $30 \mathrm{~min}$ before exenatide was injected. Exenatide and LY294002 were dissolved in dimethyl sulfoxide (DMSO). The sham-operated group and MI/R group received the same volume of DMSO for 2 weeks.

After 2 weeks of pre-treatment, all rats were anesthetized by chloral hydrate (concentration: 3.5\%,10 ml/kg). Tracheotomy was carried out for ventilation by a respirator (ALC-V8B, Alcott Biotech Co., Ltd., Shanghai, China) with a stroke volume of $28 \mathrm{ml} / \mathrm{kg}$, air pressure of $10 \mathrm{mmHg}$, respiration rate of 1:1 and at a rate of 86 strokes per minute, and a lead II electrocardiogram (ECG) was performed. Thoracotomy was performed and the left anterior descending coronary artery was then ligated using a 6-0 silk suture. Myocardial ischemia was by the presence of a zone of cyanosis and the elevation of the S-T segment in the ECG. After completion of the surgical procedure, the animals were allowed to stabilize for $30 \mathrm{~min}$ prior to reperfusion, of the previously ischemic myocardium, for $2 \mathrm{~h}$. The sham-operated group rats were subjected to the same surgical procedure, but without ligation.

Hemodynamic measurements. At the end of the MI/R period, the right common carotid artery and left femoral artery were isolated. A polystyrene PE-20 catheter was inserted into the 
left ventricle via the right common carotid artery, with one end connected to an MPA-2000 multichannel physiological recorder. The left ventricular end-systolic pressure (LVESP), the left ventricular end-diastolic pressure (LVEDP) and the rates of maximum positive and negative left ventricular pressure development $( \pm \mathrm{LVdp} / \mathrm{dtmax})$ were measured. LVESP and LVEDP were expressed as $\mathrm{mmHg}$. \pm LVdp/dtmax was expressed as $\mathrm{mmHg} / \mathrm{sec}$. All the rats were sacrificed and their hearts were collected. The blood plasma samples were collected immediately and stored at $-80^{\circ} \mathrm{C}$.

\section{2,3,5-Triphenyl tetrazolium chloride (TTC) staining} Infarct size was measured using TTC staining as previously described (17). In brief, the heart was transected parallel to the atrioventricular groove at the center of the infarct area and incubated in $1 \%$ TTC solution for $15 \mathrm{~min}$ at $37^{\circ} \mathrm{C}$. After staining, the infarct area appears pallid, whereas the viable myocardium appears red. Infarct size was expressed as the ratio of the infarct area to the total volume (volume of infarct area and viable area).

Terminal deoxynucleotidyl transferase-mediated dUTP-biotin nick end-labeling (TUNEL) staining. TUNEL staining was performed using a TUNEL staining assay kit according to the manufacturer's instructions (Boster Bio-engineering Co., Ltd., Wuhan, China). Briefly, after deparaffinization, tissue sections were first treated with $\mathrm{H}_{2} \mathrm{O}_{2}(3 \%)$ and then digested with proteinase $\mathrm{K}(20 \mu \mathrm{g} / \mathrm{ml} ; \mathrm{pH} 7.4)$ at $25^{\circ} \mathrm{C}$. Following digestion for $10 \mathrm{~min}$, the tissue sections were incubated with labeling buffer $(1: 18)$ at $37^{\circ} \mathrm{C}$. Following incubation for $120 \mathrm{~min}$, the tissue sections were incubated with biotinylated anti-digoxin antibody (1:100) for $30 \mathrm{~min}$ at $37^{\circ} \mathrm{C}$. Incorporated fluorescein was then detected with streptavidin-biotin-peroxidase and subsequently the tissue sections were dyed with 3,3'-diaminobenzidine (DAB). This assay detects apoptotic cells by labeling the 3'-OH end DNA fragments with digoxigenin-deoxyuridine triphosphate (Dig-dUTP) using terminal deoxynucleotidyl transferase. The nuclei of the apoptotic cells were stained brown and the nuclei of normal cells were stained blue. The apoptotic index (AI) was determined as the ratio of the number of brown nuclei to the total number of nuclei. Nuclei in a total of 10 fields per tissue slice $(n=6)$ were included.

Colorimetry. The activity of lactate dehydrogenase (LDH) in the culture medium and plasma, the concentrations of MDA and total superoxide dismutase (T-SOD) in the H9c2 cells and the concentrations of MDA, T-SOD, catalase and glutathione peroxidase (GSH-Px) in the heart homogenates were determined by colorimetry. The experiment was performed using commercially available kits, according to the manufacturer's instructions (Jiancheng Bioengineering Institute, Nanjing, China). Briefly, culture medium and plasma were collected. The H9c2 cells and heart tissues were collected and lysed by cell lysis buffer. The cell lysates were then centrifuged at $1,600 \mathrm{x} \mathrm{g}$ for $10 \mathrm{~min}$ at $4^{\circ} \mathrm{C}$. The supernatants of the culture medium, plasma and heart cell lysates were collected for the detection of LDH, MDA, T-SOD, catalase and GSH-Px. Following incubation with the reagents included in the kits, the absorbance values at 340, 532, 550, 450 and $412 \mathrm{~nm}$ were measured using a spectrophotometer (721D; Pudong Shanghai
Physical Optics Instrument Factory, Shanghai, China). The experiment was performed at least 3 times and the LDH level was expressed as U/1. T-SOD, catalase and GSH-Px levels were expressed as $\mathrm{U} / \mathrm{mg}$ protein. The MDA level was expressed as $\mathrm{nmol} / \mathrm{mg}$ protein.

ELISA assays. The levels of creatine kinase-MB (CK-MB) in the culture medium and plasma were measured using a CK-MB ELISA assay kit (R\&D Systems, Minneapolis, MN, USA), according to the manufacturer's instructions. After the indicated treatments, the culture medium and plasma were collected and centrifuged at $1,600 \mathrm{x}$ g for $10 \mathrm{~min}$ at $4^{\circ} \mathrm{C}$. The supernatants were collected for the detection of CK-MB. The supernatants were then incubated with the reagents included in the kits. Finally, the absorbance values were measured using a microplate reader (Molecular Devices, Downingtown, PA, USA) at $450 \mathrm{~nm}$. All experiments were performed independently at least 3 times and the CK-MB level was expressed as U/l.

Western blot analysis. The H9c2 cells and left ventricular myocardium lysates were homogenized in cell lysis buffer (Beyotime Institute of Biotechnology). Lysates were kept on ice for $45 \mathrm{~min}$ and cleared by centrifugation at $14,000 \mathrm{x} \mathrm{g}$ for $10 \mathrm{~min}$ at $4^{\circ} \mathrm{C}$ and defined as total cardiac protein. Proteins were separated by SDS-PAGE and transferred onto membranes. The membranes were blocked in 5\% bovine serum albumin (BSA) and incubated with primary antibodies against Akt (1:1,000, Cell Signaling Technology, Inc., Danvers, MA, USA), phospho-AKT $^{\text {serine473 }}$ (1:1,000, Cell Signaling Technology, Inc.), cleaved caspase-3 (1:1,000, Cell Signaling Technology, Inc.), phospho-Bad $^{\text {serine136 }}$ (1:500, Santa Cruz Biotechnology, Inc.) and anti-GAPDH antibody (1:1,000, Beyotime Institute of Biotechnology). The membranes were then incubated with a secondary antibody (Beyotime Institute of Biotechnology). The signals were detected with the ECL system (Beyotime Institute of Biotechnology). Blots were scanned using the Bio-Rad gel imaging system (Bio-Rad, Hercules, CA, USA) and bands were quantified using QuantityOne software.

Statistical analysis. SPSS 17.0 software was used for statistical analysis. Data are presented as the means \pm standard deviation (SD). Group data were analyzed using a one-way analysis of variance (ANOVA) followed by the Student-Newman-Keuls test. When the equal variance test failed, a Mann-Whitney Rank Sum test was used. Values of $\mathrm{P}<0.05$ were considered to indicate statistically significant differences.

\section{Results}

Exenatide increases the viability of $\mathrm{H}_{2} \mathrm{O}_{2}$-treated $\mathrm{H} 9 \mathrm{c} 2$ cells. After the $\mathrm{H} 9 \mathrm{c} 2$ cells were exposed to various concentrations of $\mathrm{H}_{2} \mathrm{O}_{2}(50,100,200$ and $400 \mu \mathrm{M})$ for $6 \mathrm{~h}$, MTT assay was performed to determine the viability of the $\mathrm{H}_{2} \mathrm{O}_{2}$-treated $\mathrm{H} 9 \mathrm{c} 2$ cells and to determine the most effective concentration. The increasing concentration of $\mathrm{H}_{2} \mathrm{O}_{2}$ led to the intensified damage of $\mathrm{H} 9 \mathrm{c} 2$ cells (Fig. 1A). When the cells were exposed to 50 and $100 \mu \mathrm{M} \mathrm{H}_{2} \mathrm{O}_{2}$ their viability was reduced to 85.08 and $78.08 \%$, respectively compared with that of the control group $(\mathrm{P}<0.05)$, while when exposed to 200 and $400 \mu \mathrm{M} \mathrm{H}_{2} \mathrm{O}_{2}$ 

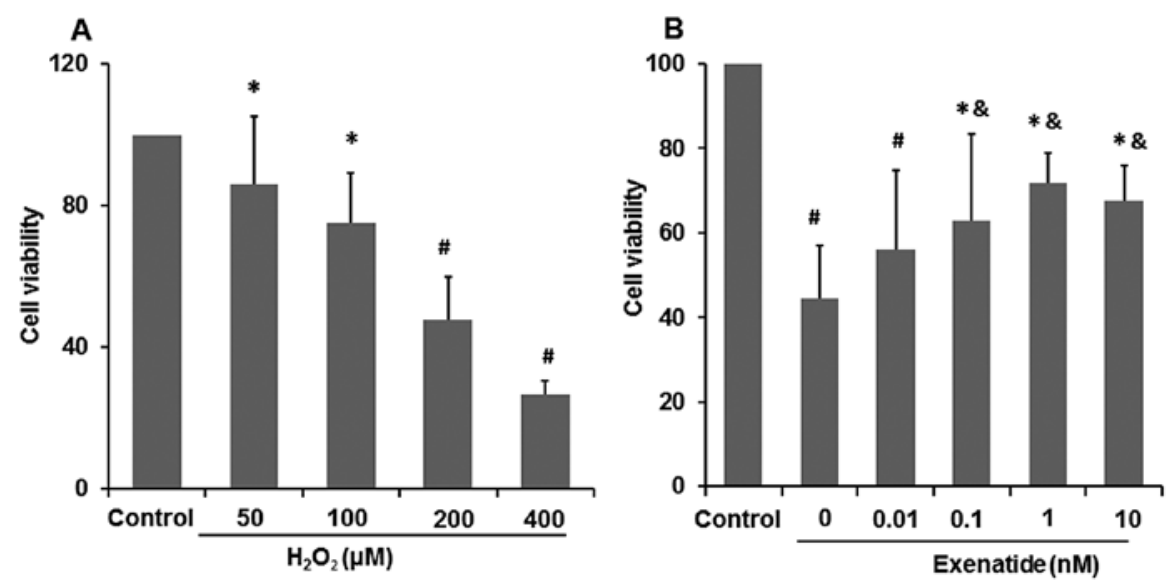

Figure 1. Effects of $\mathrm{H}_{2} \mathrm{O}_{2}$ and exenatide on the viability of $\mathrm{H} 9 \mathrm{c} 2$ cells. (A) Effects of $\mathrm{H}_{2} \mathrm{O}_{2}$ on the viability of $\mathrm{H} 9 \mathrm{c} 2$ cells. $\mathrm{H} 9 \mathrm{c} 2$ cells were exposed to various concentrations of $\mathrm{H}_{2} \mathrm{O}_{2}(50,100,200$ and $400 \mu \mathrm{M})$. (B) Effects of exenatide on the viability of $\mathrm{H} 9 \mathrm{c} 2$ cells. $\mathrm{H} 9 \mathrm{c} 2$ cells were pre-treated with various concentrations of exenatide $(0,0.01,0.1,1$ and $10 \mathrm{nM})$ for $30 \mathrm{~min}$ prior to exposure to $\mathrm{H}_{2} \mathrm{O}_{2}(200 \mu \mathrm{M}, 6 \mathrm{~h})$. Following treatment, cell viability was assessed by MTT assay. Data are expressed as a percentage of the control and are presented as the means $\pm \mathrm{SD}, \mathrm{n}=6 .{ }^{*} \mathrm{P}<0.05 ;{ }^{*} \mathrm{P}<0.01$ vs. control group. ${ }^{\text {\& }} \mathrm{P}<0.05$ vs. 0 group.

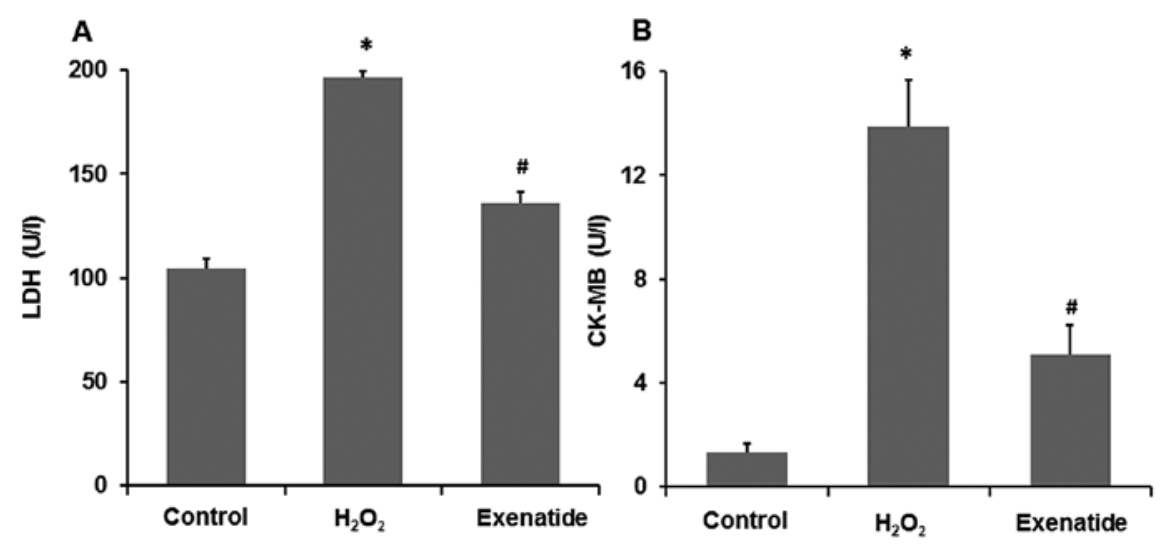

Figure 2. Effects of exenatide on LDH and CK-MB levels in the culture medium. Following pre-treatment with $1 \mathrm{nM}$ exenatide for 30 min, the cells were exposed to $\mathrm{H}_{2} \mathrm{O}_{2}$ (200 $\mu \mathrm{M}$ for $6 \mathrm{~h}$ ). (A) Effects of exenatide on the LDH levels in the culture medium. LDH levels in the culture medium were measured by colorimetry and were expressed as U/l. (B) Effects of exenatide on CK-MB levels in the culture medium. CK-MB levels in the culture medium were detected by ELISA assay and were expressed as U/1. LDH, lactate dehydrogenase; CK-MB, creatine kinase-MB. Values were expressed as the means \pm SD. $n=6$. ${ }^{*} \mathrm{P}<0.05$ vs. control group. ${ }^{\#} \mathrm{P}<0.05$ vs. $\mathrm{H}_{2} \mathrm{O}_{2}$ group.

their viability was reduced to 47.6 and $26.35 \%$, respectively compared with that of the control group $(\mathrm{P}<0.01)$. Finally, the concentration of $200 \mu \mathrm{M} \mathrm{H}_{2} \mathrm{O}_{2}$ was selected for the study of the medium cellular mortality and of the damage induced by oxidative stress.

To investigate the possible protective effects of exenatide on oxidative stress-induced injury, the cells were pre-treated with exenatide $(0,0.01,0.1,1$ and $10 \mathrm{nM})$ for $30 \mathrm{~min}$ prior to exposure to $\mathrm{H}_{2} \mathrm{O}_{2}$. We found that pre-treatment with $0.1,1$ and $10 \mathrm{nM}$ exenatide statistically increased cell viability which was decreased by oxidative stress-induced injury $(\mathrm{P}<0.05)$ (Fig. 1B). These results strongly suggest that exenatide exerts cardiomyocyte protective effects against oxidative stressinduced injury in $\mathrm{H} 9 \mathrm{c} 2$ cells. Exenatide, at a concentration of $1 \mathrm{nM}$, had the optimal protective effects on cell viability. Thus, it was selected for the following experiments.

Exenatide protects $\mathrm{H} 9 \mathrm{c} 2$ cells against oxidative stressinduced injury following exposure to $\mathrm{H}_{2} \mathrm{O}_{2}$. As $\mathrm{LDH}$ and
CK-MB are two acknowledged markers of cell damage, we further assessed the release of $\mathrm{LDH}$ and CK-MB in the culture medium (Fig. 2A and B). Compared with the levels in the control group, the LDH and CK-MB levels were significantly increased in the $\mathrm{H}_{2} \mathrm{O}_{2}$ group $(\mathrm{P}<0.05)$, while the $\mathrm{H} 9 \mathrm{c} 2$ cells pretreated with $1 \mathrm{nM}$ exenatide presented a significant decrease in the $\mathrm{H}_{2} \mathrm{O}_{2}$-induced release of $\mathrm{LDH}$ and CK-MB $(\mathrm{P}<0.05)$. These results further indicate that exenatide exerts cardiomyocyte protective effects against oxidative stress-induced injury in $\mathrm{H} 9 \mathrm{c} 2$ cells.

Exenatide reduces $\mathrm{H}_{2} \mathrm{O}_{2}$-mediated oxidative stress in $\mathrm{H} 9 \mathrm{c} 2$ cells. To further determine the effects of exenatide on oxidative stress induced by $\mathrm{H}_{2} \mathrm{O}_{2}$, the intracellular levels of ROS, T-SOD and MDA were measured (Fig. 3A-D). ROS and MDA levels were significantly increased in the $\mathrm{H}_{2} \mathrm{O}_{2}$ group compared with those in the control group $(\mathrm{P}<0.05)$, while the T-SOD level was significantly decreased $(\mathrm{P}<0.05)$. Exenatide at the concentration of $1 \mathrm{nM}$, which was administered $30 \mathrm{~min}$ 
A
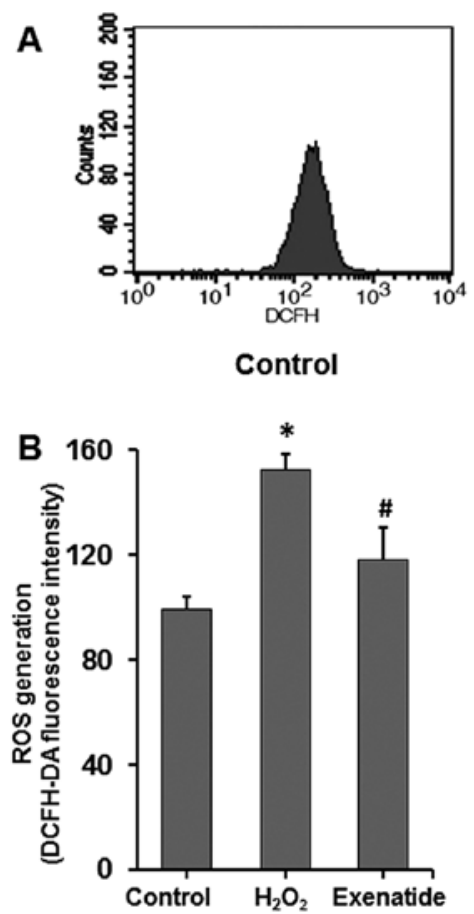
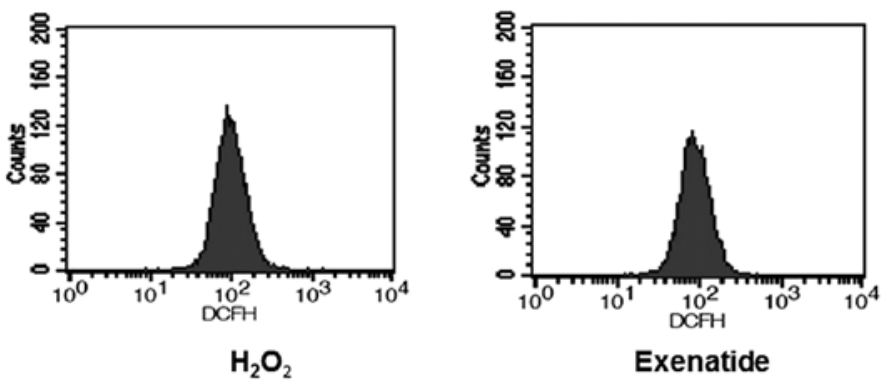

C

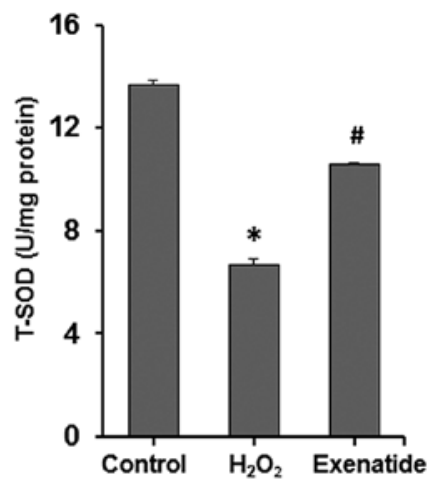

D

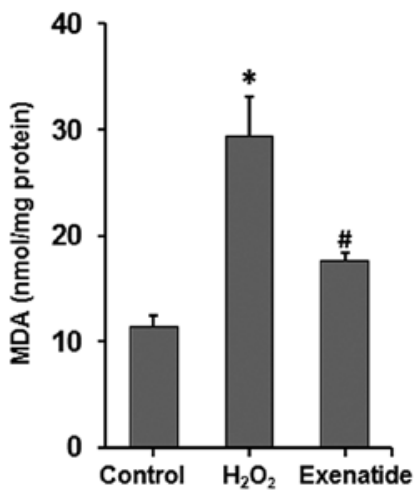

Figure 3. Effects of exenatide on ROS, T-SOD and MDA levels in $\mathrm{H}_{2} \mathrm{O}_{2}$-treated $\mathrm{H} 9 \mathrm{c} 2$ cells. Cells were pre-treated with 1 nM exenatide for 30 min and then exposed to $\mathrm{H}_{2} \mathrm{O}_{2}\left(200 \mu \mathrm{M}, 6\right.$ h). (A) Representative flow cytometry results of ROS generation in $\mathrm{H}_{2} \mathrm{O}_{2}$-treated $\mathrm{H} 9 \mathrm{c} 2$ cells. ROS generation was estimated using the probe, DCFH-DA, by flow cytometry. (B) Quantitative analyses of ROS generation in $\mathrm{H}_{2} \mathrm{O}_{2}$-treated $\mathrm{H} 9 \mathrm{c} 2$ cells. The data are expressed as the means of fluorescence intensity. (C) Effects of exenatide on T-SOD levels in $\mathrm{H}_{2} \mathrm{O}_{2}$-treated $\mathrm{H} 9 \mathrm{c} 2$ cells. T-SOD levels were measured by colorimetry and expressed as U/mg protein. (D) Effects of exenatide on MDA levels in $\mathrm{H}_{2} \mathrm{O}_{2}$-treated $\mathrm{H} 9 \mathrm{c} 2$ cells. MDA levels were measured by colorimetry and expressed as nmol/mg protein. ROS, reactive oxygen species; T-SOD, total superoxide dismutase; MDA, malondialdehyde. Values are expressed as the means $\pm \mathrm{SD}$, $\mathrm{n}=3$. ${ }^{*} \mathrm{P}<0.05$ vs. control group. ${ }^{\#} \mathrm{P}<0.05$ vs. $\mathrm{H}_{2} \mathrm{O}_{2}$ group.

prior to exposure to $\mathrm{H}_{2} \mathrm{O}_{2}$, increased the T-SOD level $(\mathrm{P}<0.05)$ and decreased ROS and MDA levels $(\mathrm{P}<0.05)$. These results indicated that exenatide reduced oxidative stress induced by $\mathrm{H}_{2} \mathrm{O}_{2}$ by scavenging oxidative stress products (ROS and MDA) and increasing the concentration of antioxidant defense enzymes (SOD) in H9c2 cells.

Exenatide decreases myocardial injury in the rats with $M I / R$-induced injury. To determine the effects of exenatide on myocardial injury in the rats with MI/R-induced injury, infarct size and the release of LDH and CK-MB in the plasma were measured. As shown in Fig. 4A-D, 30 min of ischemia and $2 \mathrm{~h}$ of reperfusion resulted in an increased infarct size, as well as an increase in LDH and CK-MB levels $(\mathrm{P}<0.05)$. Following pre-treatment with exenatide, infarct size was significantly decreased compared with the MI/R group $(\mathrm{P}<0.05)$. Simultaneously, LDH and CK-MB levels were significantly reduced in the exenatide group compared with those in the $\mathrm{MI} / \mathrm{R}$ group $(\mathrm{P}<0.05)$. These results suggest that exenatide decreases myocardial injury induced by $\mathrm{MI} / \mathrm{R}$ in rats.

Exenatide reduces $M I / R$-mediated oxidative stress in heart homogenates. To further determine the effects of exenatide on oxidative stress induced by MI/R, the homogenate levels of catalase, T-SOD, GSH-Px and MDA were measured (Fig. 5A-D). Catalase, T-SOD and GSH-Px levels were significantly decreased in the $\mathrm{MI} / \mathrm{R}$ group $(\mathrm{P}<0.05)$, while MDA levels were significantly increased $(\mathrm{P}<0.05)$, compared with those in the sham-operated group. Exenatide at a dose of
$10 \mu \mathrm{g} / \mathrm{kg} /$ day increased catalase, T-SOD and GSH-Px levels $(\mathrm{P}<0.05)$ and decreased MDA levels $(\mathrm{P}<0.05)$ compared with those in the $\mathrm{MI} / \mathrm{R}$ group. These results suggest that exenatide reduces oxidative stress induced by MI/R by scavenging oxidative stress products (MDA) and increasing the concentration of antioxidant defense enzymes (catalase, T-SOD and GSH-Px).

Exenatide enhances left ventricular function in rats with $M I / R$-induced injury. To determine the effects of exenatide on cardiac function in the rats with MI/R-induced injury, hemodynamic measurements were performed at the end of the MI/R period. As shown in Fig. 6, compared with the shamoperated group, MI/R significantly decreased +LVdp/dtmax, -LVdp/dtmax and LVESP $(\mathrm{P}<0.05)$, while it significantly increased LVEDP $(\mathrm{P}<0.05)$. Compared with the MI/R group, exenatide significantly enhanced $+\mathrm{LVdp} / \mathrm{dtmax},-\mathrm{LVdp} / \mathrm{dtmax}$, LVESP $(\mathrm{P}<0.05)$, but significantly reduced LVEDP $(\mathrm{P}<0.05)$, suggesting that the left ventricular function was enhanced by exenatide pre-treatment in the rats with MI/R-induced injury.

Exenatide reduces $\mathrm{H} 9 \mathrm{c} 2$ cell apoptosis induced by $\mathrm{H}_{2} \mathrm{O}_{2}$ and cardiomyocyte apoptosis induced by MI/R. To investigate the anti-apoptotic effects of exenatide, we measured the apoptotic ratio of $\mathrm{H} 9 \mathrm{c} 2$ cells and cardiomyocytes in the rats. The PI3K inhibitor, LY294002, was employed to determine the mechanisms behind the anti-apoptotic effects of exenatide (Fig. 7).

Firstly, we investigated the anti-apoptotic effects of exenatide in the H9c2 cells by flow cytometry (Fig. 7A and C). The apoptotic ratio of $\mathrm{H} 9 \mathrm{c} 2$ cells was significantly increased in 
A

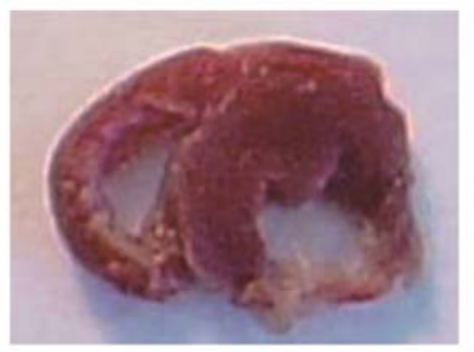

Sham

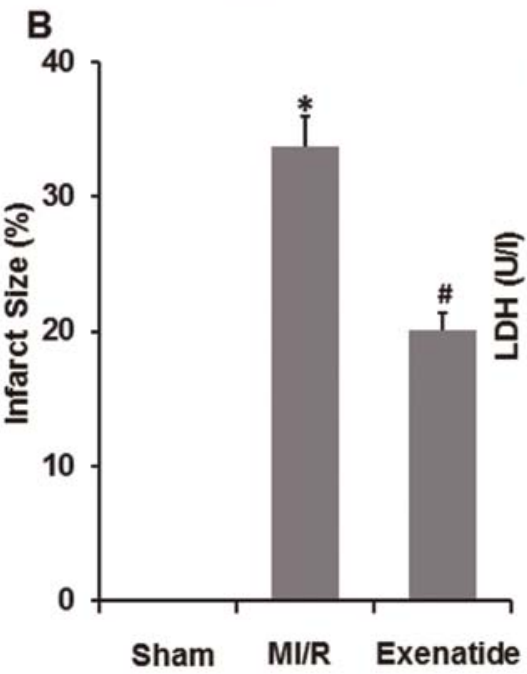

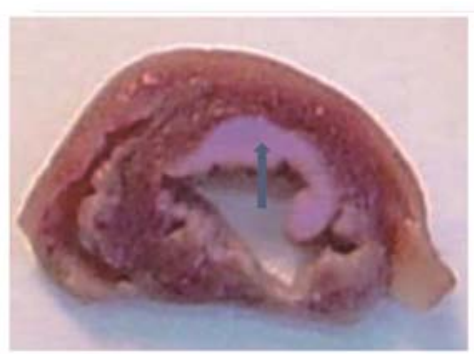

MI/R

C

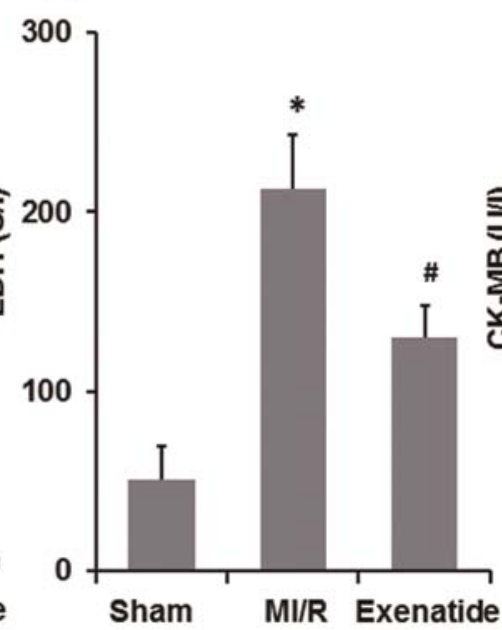

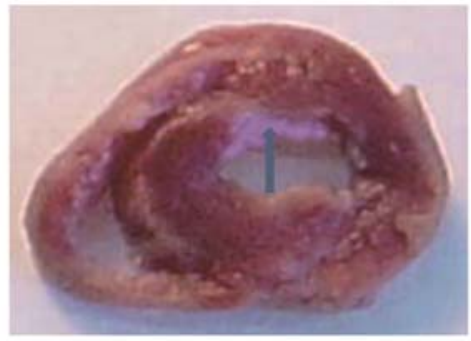

Exenatide

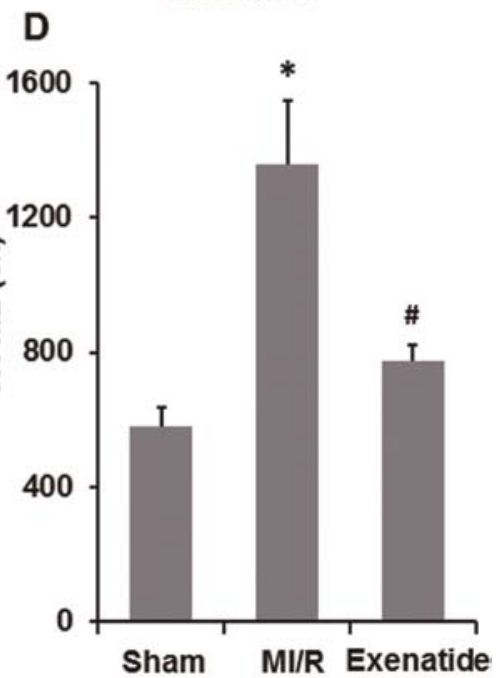

Figure 4. Effects of exenatide on infarct size, LDH and CK-MB in the rats with MI/R-induced injury. Following pre-treatment with exenatide (10 $\mu \mathrm{g} / \mathrm{kg} / \mathrm{day})$ for 2 weeks, the rats were subjected to myocardial ischemia/reperfusion $(30 \mathrm{~min} / 2 \mathrm{~h}$ ). (A) Representative images of the TTC staining results to determine infarct size. The arrows indicate the infarct area. (B) Quantitative analyses of infarct size. Infarct size was expressed as the percentage of total volume. (C) Effects of exenatide on LDH levels in the plasma of the rats with MI/R-induced injury. LDH levels were measured by colorimetry and expressed as U/l. (D) Effects of exenatide on CK-MB levels in the plasma of the rats with MI/R-induced injury. CK-MB level in plasma of the rats with MI/R-induced injury were detected by ELISA assay. CK-MB levels were expressed as U/l. LDH, lactate dehydrogenase; CK-MB, creatine kinase-MB; MI/R, myocardial ischemia/reperfusion. Values are expressed as the means $\pm \mathrm{SD} . \mathrm{n}=6 .{ }^{*} \mathrm{P}<0.05$ vs. sham-operated group. ${ }^{*} \mathrm{P}<0.05$ vs. $\mathrm{MI} / \mathrm{R}$ group.
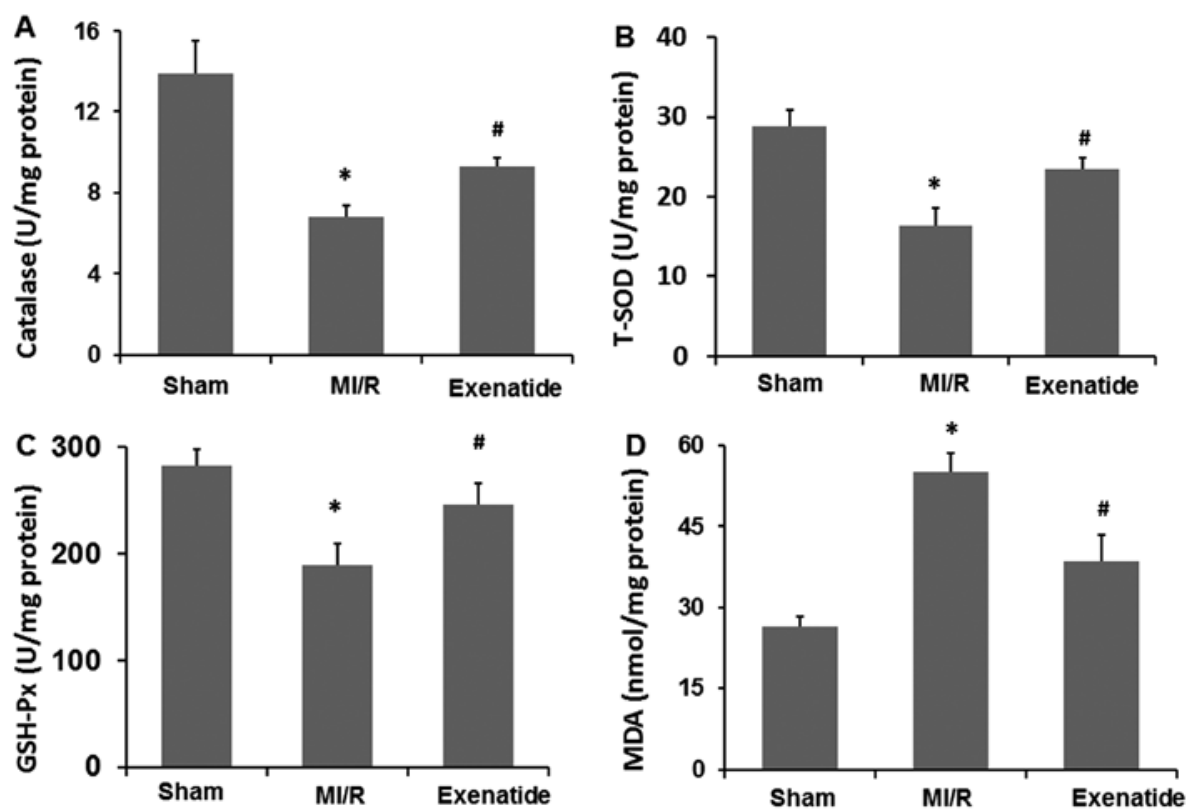

Figure 5. Effects of exenatide on catalase, T-SOD, GSH-Px and MDA levels in heart homogenates. Following pre-treatment with exenatide (10 $\mu \mathrm{g} / \mathrm{kg} / \mathrm{day})$ for 2 weeks, the rats were subjected to myocardial ischemia/reperfusion $(30 \mathrm{~min} / 2 \mathrm{~h}$ ). (A) Effects of exenatide on catalase levels in heart homogenates. (B) Effects of exenatide on T-SOD levels in heart homogenates. (C) Effects of exenatide on GSH-Px levels in heart homogenates. (D) Effects of exenatide on MDA levels in heart homogenates. Catalase, T-SOD, GSH-Px and MDA levels in heart homogenates were measured by colorimetry. Catalase, T-SOD and GSH-Px levels were expressed as U/mg protein. MDA levels were expressed as nmol/mg protein. T-SOD, total superoxide dismutase; GSH-Px, glutathione peroxidase; MDA, malondialdehyde. Values are expressed as the means \pm SD. $n=6$. ${ }^{*} \mathrm{P}<0.05$ vs. sham-operated group. ${ }^{*} \mathrm{P}<0.05$ vs. MI/R group. 
A

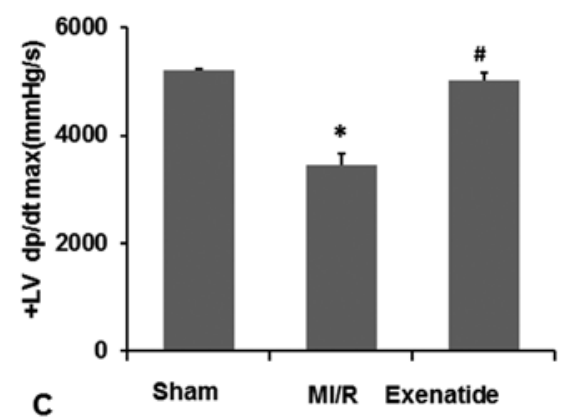

C

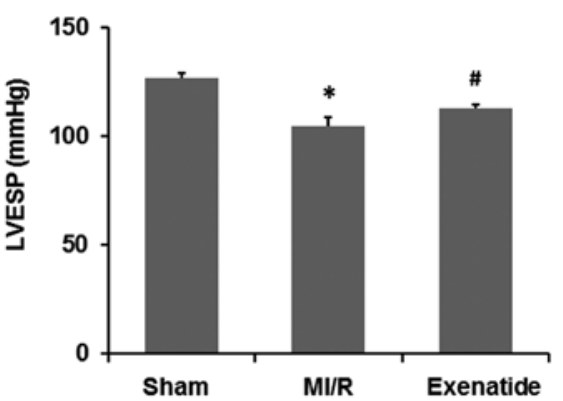

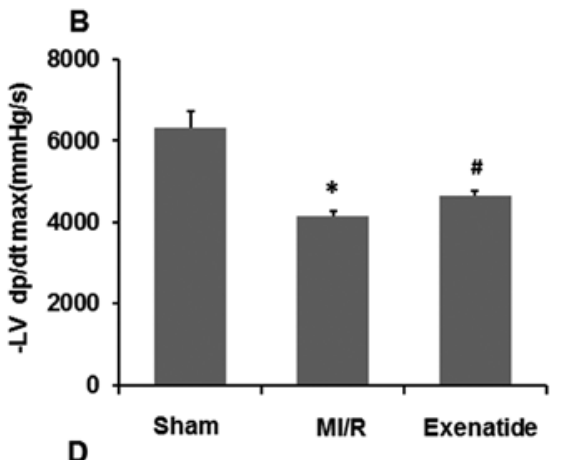

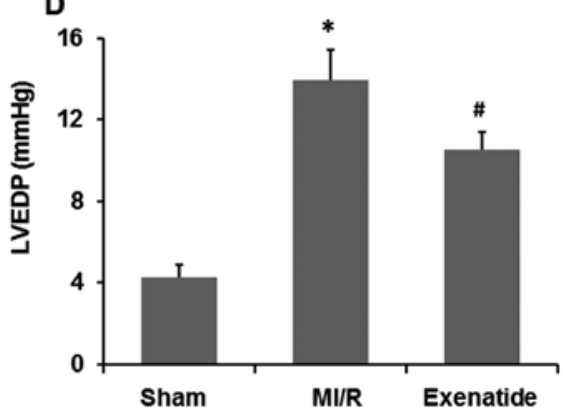

Figure 6. Effects of exenatide on left ventricular function in the rats with MI/R-induced injury. Following pre-treatment with exenatide (10 $\mu \mathrm{g} / \mathrm{kg} / \mathrm{day})$ for 2 weeks, the rats were subjected to myocardial ischemia/reperfusion (30 min/2 h). (A) Effects of exenatide on +LVdp/dtmax. (B) Effects of exenatide on -LVdp/dtmax. (C) Effects of exenatide on LVESP. (D) Effects of exenatide on LVEDP \pm LVdP/dtmax, LVESP and LVEDP were measured using a multichannel physiological recorder. \pm LVdP/dtmax was expressed as $\mathrm{mmHg} / \mathrm{sec}$. LVESP and LVEDP were expressed as mmHg. MI/R, myocardial ischemia/reperfusion; $+\mathrm{LVdP} / \mathrm{dtmax}$, rate of maximum positive left ventricular pressure development; -LVdP/dtmax, rate of maximum negative left ventricular pressure development; LVESP, left ventricular end-systolic pressure; LVEDP, left ventricular end-diastolic pressure. Values are expressed as the means $\pm \mathrm{SD}$. $\mathrm{n}=8$. ${ }^{*} \mathrm{P}<0.05 \mathrm{vs}$. shamoperated group. ${ }^{~} \mathrm{P}<0.05$ vs, $\mathrm{MI} / \mathrm{R}$ group.
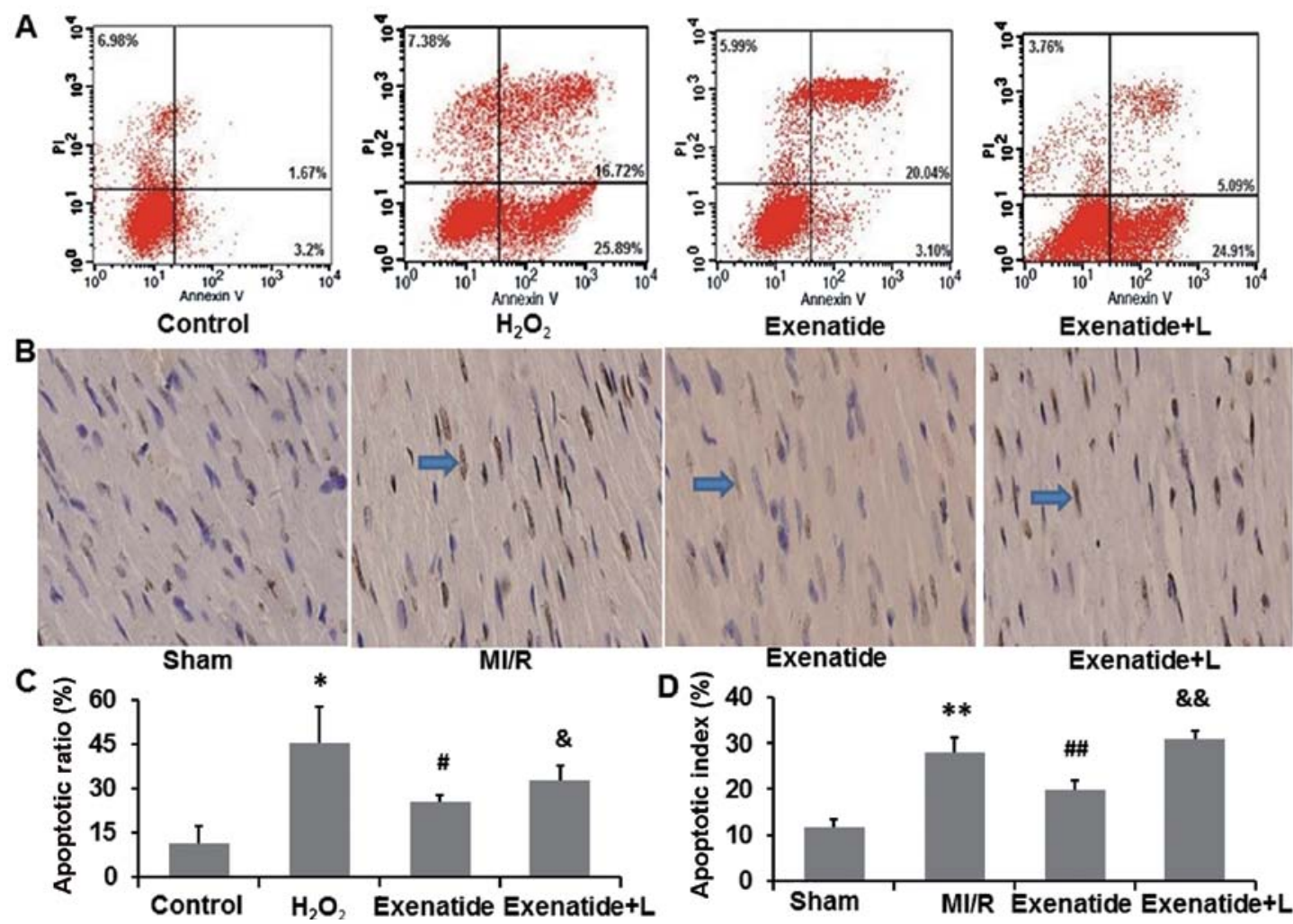

Figure 7. Effects of exenatide on apoptosis in $\mathrm{H}_{2} \mathrm{O}_{2}$-treated $\mathrm{H} 9 \mathrm{c} 2$ cells and in the rats with MI/R-induced injury. Following pre-treatment with $1 \mathrm{nM}$ exenatide for $30 \mathrm{~min}$, the cells were subjected to $\mathrm{H}_{2} \mathrm{O}_{2}(200 \mu \mathrm{M}, 6 \mathrm{~h})$. Following pre-treatment with exenatide $(10 \mu \mathrm{g} / \mathrm{kg} / \mathrm{day})$ for 2 weeks, the rats were subjected to MI/R (30 min/2 h). Apoptosis was analyzed by flow cytometry analysis and TUNEL staining assay. (A) Representative flow cytometry results. (B) Representative graphical images of TUNEL staining (x400). The arrows indicate the nuclei of the apoptotic cells. (C) Quantitative results of flow cytometry. The apoptotic ratio was determined as the ratio of the number of Annexin V-positive and PI-negative cells to total number of cells analyzed; $n=3$. (D) Quantitative results of TUNEL staining. AI was determined as the ratio of the number of brown nuclei to the total number of nuclei. Nuclei in a total of 10 fields per tissue slice $(\mathrm{n}=6)$ were included. MI/R, myocardial ischemia/reperfusion; PI, propidium iodide; $\mathrm{AI}$, apoptotic index. Values are expressed as the means $\pm \mathrm{SD}$. " $\mathrm{P}<0.05 \mathrm{vs}$. control group; ${ }^{*} \mathrm{P}<0.05$ vs. $\mathrm{H}_{2} \mathrm{O}_{2}$ group; ${ }^{\circledR} \mathrm{P}<0.05$ vs. exenatide group. ${ }^{* *} \mathrm{P}<0.05$ vs. sham-operated group. ${ }^{* \#} \mathrm{P}<0.05$ vs. MI $/ \mathrm{R}$ group. ${ }^{\text {\&\&}} \mathrm{P}<0.05$ vs. exenatide group. 

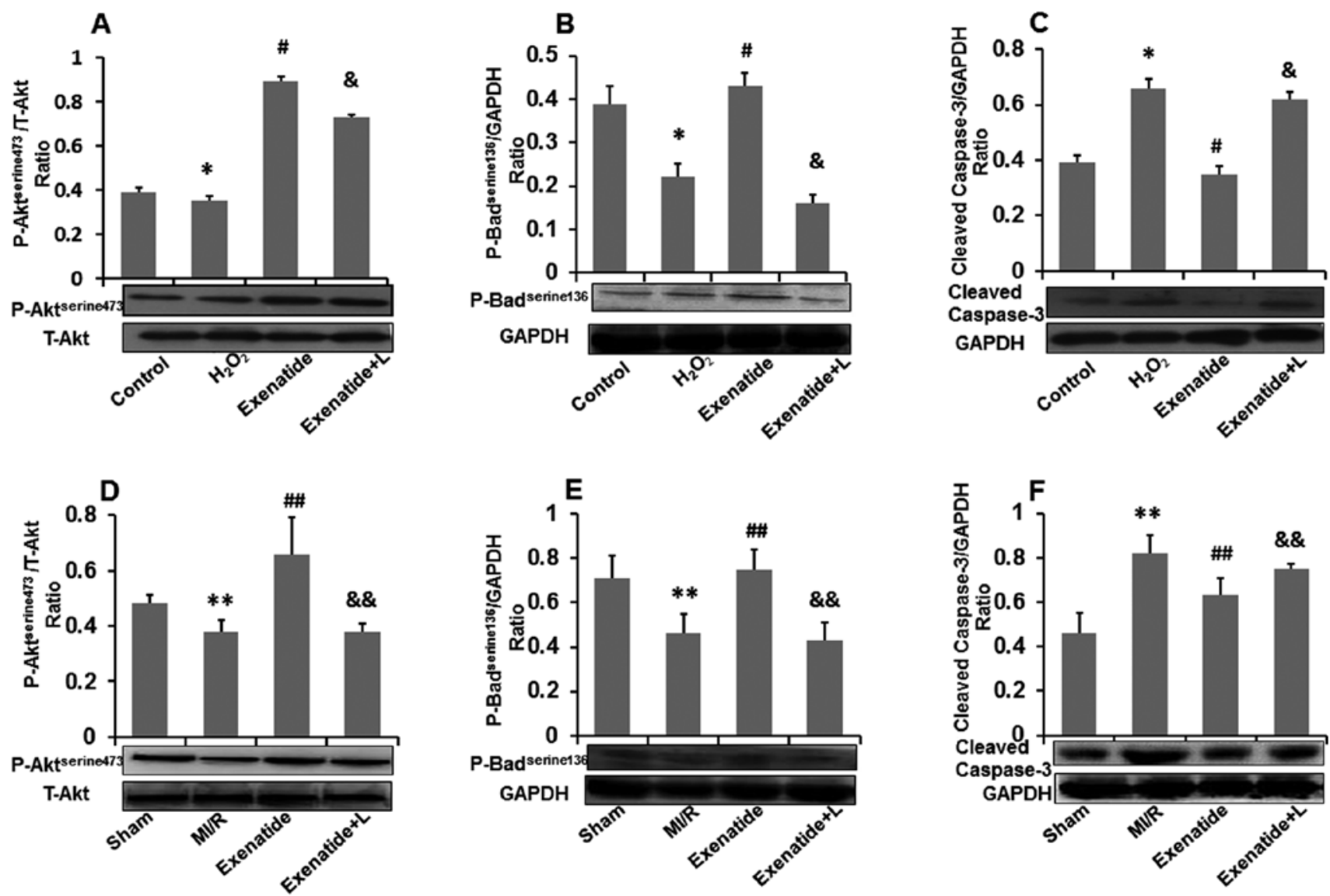

Figure 8. Effects of exenatide on Akt ${ }^{\text {serine } 473}$ and $\mathrm{Bad}^{\text {serine136 }}$ phosphorylation and cleaved caspase- 3 expression in $\mathrm{H}_{2} \mathrm{O}_{2}$-treated $\mathrm{H} 9 \mathrm{c} 2$ cells and in the rats with MI/R-induced injury. Following pre-treatment with $1 \mathrm{nM}$ exenatide for $30 \mathrm{~min}$, the cells were exposed to $\mathrm{H}_{2} \mathrm{O}_{2}(200 \mu \mathrm{M}, 6 \mathrm{~h})$. Following pre-treatment with exenatide $(10 \mu \mathrm{g} / \mathrm{kg} / \mathrm{day})$ for 2 weeks, the rats were subjected to MI/R $(30 \mathrm{~min} / 2 \mathrm{~h})$. Akt ${ }^{\text {serine } 473}$ and $\mathrm{Bad}^{\text {serinel } 136}$ phosphorylation and cleaved caspase-3 expression were analyzed by western blot analysis. (A) Ratios of phospho-Akt ${ }^{\text {serine } 473}$ to total Akt and representative western blot analysis results in H9c2 cells. (B) Ratios of phospho-Bad ${ }^{\text {erinel } 36}$ to GAPDH and representative western blot analysis results in H9c2 cells. (C) Ratios of cleaved caspase-3 to GAPDH and representative western blot analysis results in $\mathrm{H} 9 \mathrm{c} 2$ cells. (D) Ratios of phospho-Akt ${ }^{\text {serine } 473}$ to total Akt and representative western blot analysis results in myocardial tissue. (E) Ratios of phospho-Bad ${ }^{\text {serine } 136}$ to GAPDH and representative western blot analysis results in myocardial tissue. (F) Ratios of cleaved caspase-3 to GAPDH and representative western blot analysis results in myocardial tissue. MI/R, myocardial ischemia/reperfusion. Values are expressed as the means \pm SD. ${ }^{*} \mathrm{P}<0.05 \mathrm{vs}$. control group; ${ }^{\#} \mathrm{P}<0.05$ vs. $\mathrm{H}_{2} \mathrm{O}_{2}$ group; ${ }^{\&} \mathrm{P}<0.05$ vs. exenatide group. ${ }^{* *} \mathrm{P}<0.05$ vs. sham-operated group. ${ }^{* \#} \mathrm{P}<0.05$ vs. MI/R group. ${ }^{\text {\& }} \mathrm{P}<0.05$ vs. exenatide group.

the $\mathrm{H}_{2} \mathrm{O}_{2}$ group compared with the control group $(\mathrm{P}<0.05)$. Following pre-treatment with exenatide, the apoptotic ratio was decreased compared with the $\mathrm{H}_{2} \mathrm{O}_{2}$ group $(\mathrm{P}<0.05)$, indicating that exenatide protected the $\mathrm{H} 9 \mathrm{c} 2$ cells from $\mathrm{H}_{2} \mathrm{O}_{2}$-induced apoptosis. However, the anti-apoptotic effects of exenatide were attenuated in the presence of LY294002, suggesting that LY294002 inhibited the anti-apoptotic effects of exenatide in H9c2 cells.

We also examined the anti-apoptotic effects of exenatide on cardiomyocytes in myocardial tissue by TUNEL staining (Fig. 7B and D). We found that the apoptotic index was significantly increased in the MI/R group compared with the sham-operated group $(\mathrm{P}<0.05)$. The apoptotic index was significantly decreased in the exenatide group compared with that in the $\mathrm{MI} / \mathrm{R}$ group $(\mathrm{P}<0.05)$. Moreover, the apoptotic index was significantly higher in the exenatide $+\mathrm{L}$ group than the exenatide group $(\mathrm{P}<0.05)$, suggesting that LY294002 inhibited the anti-apoptotic effects of exenatide in the rats with MI/R-induced injury.

Thus, our flow cytometry and TUNEL staining results indicated that exenatide suppressed apoptosis in vitro and in vivo and that these effects were attenuated by the PI3K inhibitor, LY294002.

Exenatide increases Akt $t^{\text {serine } 473}$ and Bad ${ }^{\text {serinel36 }}$ phosphorylation and decreases cleaved caspase-3 expression. To investigate the anti-apoptotic effects of exenatide against oxidative stress-induced injury, we further assessed the effects of exenatide on phospho-Akt $\mathrm{T}^{\text {serine } 473}$, phospho-Bad ${ }^{\text {serine136 }}$ and cleaved caspase-3 levels in $\mathrm{H} 9 \mathrm{c} 2$ cells and in myocardial tissue (Fig. 8). The representative western blot analysis results and the results from quantitative analysis are shown in Fig. $8 \mathrm{~A}-\mathrm{F}$.

As shown in Fig. 8A and $\mathrm{B}, \mathrm{H}_{2} \mathrm{O}_{2}$ treatment significantly reduced the levels of phospho-Akt $\mathrm{serine}^{\mathrm{s} 73}(\mathrm{P}<0.05)$ and phospho$\mathrm{Bad}^{\text {serinel36 }}(\mathrm{P}<0.05)$ compared with those in the control group. Compared with the $\mathrm{H}_{2} \mathrm{O}_{2}$ group, pre-treatment with exenatide increased the levels of phospho-AKT ${ }^{\text {serine } 473}(\mathrm{P}<0.05)$ and phospho-Bad $^{\text {serine136 }}(\mathrm{P}<0.05)$. The PI3k inhibitor, LY29002, attenuated the effects of exenatide on the increased phospho-

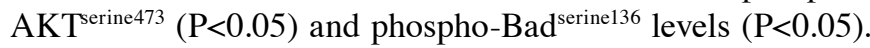
As shown in Fig. 8C, exposure to $\mathrm{H}_{2} \mathrm{O}_{2}$ increased cleaved caspase-3 expression $(\mathrm{P}<0.05)$ compared with the control 
group, whereas pre-treatment of the H9c2 cells with exenatide reduced cleaved caspase-3 expression $(\mathrm{P}<0.05)$. Similarly, the PI3K inhibitor, LY294002, attenuated the effects of exenatide on the decreased cleaved caspase-3 expression $(\mathrm{P}<0.05)$.

We also examined changes in the levels of phospho-AKT ${ }^{\text {serine473}}$, phospho-Bad ${ }^{\text {serine136 }}$ and cleaved caspase-3 in myocardial tissue (Fig. 8D-F). The levels of phospho-AKT ${ }^{\text {serine } 473}$ and phospho-Bad ${ }^{\text {serine136 }}$ in myocardial tissue were significantly decreased $(\mathrm{P}<0.05)$ in the MI/R group compared with those in the sham-operated group, contrary to the expression of cleaved caspase- 3 which was significantly increased $(\mathrm{P}<0.05)$. The levels of phospho-AKT ${ }^{\text {serine } 473}$ and phospho-Bad ${ }^{\text {serine136 }}$ in the exenatide group were significantly higher than those in the MI/R group $(\mathrm{P}<0.05)$ and the expression of cleaved caspase- 3 in the exenatide group was significantly lower than that in the MI/R group $(\mathrm{P}<0.05)$. The levels of phospho-AKT ${ }^{\text {serine } 473}$ and phospho-Bad ${ }^{\text {serine136}}$ were significantly decreased $(\mathrm{P}<0.05)$ in the exenatide $+\mathrm{L}$ group, contrary to the expression of cleaved caspase- 3 which was significantly increased $(\mathrm{P}<0.05)$.

Thus, it can be hypothesized that exenatide inhibits apoptosis in vitro and in vivo, at least in part, through the PI3K/Akt pathway.

\section{Discussion}

In the present study, we evaluated the protective effects of exenatide on oxidative stress-induced injury. We found that pre-treatment with exenatide protected cardiomyocytes against oxidative stress induced by $\mathrm{H}_{2} \mathrm{O}_{2}$ and $\mathrm{MI} / \mathrm{R}$ by increasing cell viability, decreasing the levels of cardiac injury makers (LDH and CK-MB), reducing infarct size, enhancing cardiac function and inhibiting cell apoptosis. The mechanisms behind these protective effects may be attributed to the scavenging of oxidative stress products, such as ROS and MDA, the increase in the concentration of antioxidant defense enzymes, such as catalase, SOD and GSH-Px and the inhibition of cardiomyocyte apoptosis. Our results also suggest that exenatide inhibits cardiomyocyte apoptosis, at least in part, through the PI3K/Akt pathway.

Oxidative stress products, such as ROS, are considered to be important factors inducing myocardial injury during MI/R $(3,18)$, whereas treatment with antioxidant agents or the upregulation of endogenous antioxidant enzymes in animals have been shown to exert cardioprotective effects against MI/R-induced injury $(18,19)$. ROS and MDA are the products of oxidative stress, which reflect the cell damage caused by oxidative stress. Catalase, SOD and GSH-Px, by inhibiting $\mathrm{O}_{2}$ and $\mathrm{H}_{2} \mathrm{O}_{2}$ interaction, constitute the first line of cellular defense against oxidative injury (20). In the present study, we demonstrated that exposure to $\mathrm{H}_{2} \mathrm{O}_{2}(6 \mathrm{~h})$ in vitro and $\mathrm{MI} / \mathrm{R}$ (30 min/2 h) in vivo significantly increased the levels of oxidative stress products (ROS and MDA), decreased the concentrations of antioxidant defense enzymes (catalase, T-SOD and GSH-Px) and aggravated myocardial injury; these results are in line with previous reports $(21,22)$. Importantly, in this study, the rats treated with exenatide had enhanced activities of antioxidant defense enzymes (catalase, T-SOD and GSH-Px), but lower MDA production in comparison with the rats with MI/Rinduced injury. Similarly, we found that exenatide significantly increased the levels of T-SOD and decreased the levels of ROS and MDA in the $\mathrm{H}_{2} \mathrm{O}_{2}$-treated $\mathrm{H} 9 \mathrm{c} 2$ cells. A recent study reported that the GLP-1 receptor agonist, exendin-4, increased SOD levels and decreased MDA levels in neonatal rats with hyperglycemia-induced cardiomyocytes injury (23). Our results suggest that exenatide regulates the levels of endogenous antioxidant enzymes and oxidative stress products in $\mathrm{H}_{2} \mathrm{O}_{2}$-treated $\mathrm{H} 9 \mathrm{c} 2$ cells and rats with MI/R-induced injury.

Cytosolic enzymes, such as CK-MB and LDH, which leak out from damaged tissues to the blood stream when the cell membrane becomes permeable or ruptures, serve as diagnostic markers of myocardial cell injury (24). In the present study, the activities of LDH and CK-MB were significantly increased in the $\mathrm{H}_{2} \mathrm{O}_{2}$-treated $\mathrm{H} 9 \mathrm{c} 2$ cell conditioned medium and in the plasma of rats with MI/R-induced injury. However, the increased levels of $\mathrm{LDH}$ and $\mathrm{CK}-\mathrm{MB}$ were significantly suppressed in the exenatide pre-treated $\mathrm{H} 9 \mathrm{c} 2$ cells and rats. Our findings in vitro are consistent with previous reports in which GLP-1 decreased the LDH and CK-MB levels in neonatal rat cardiomyocytes $(23,25)$. We also found that exenatide pre-treatment significantly reduced the infarct size in the rats with MI/R-induced injury; this result is in line with previous reports $(12,26)$. As previously reported $(22,27,28)$, we also found that $\mathrm{MI} / \mathrm{R}$ impairs cardiac function in rats. More importantly, we found that exenatide pre-treatment significantly improved cardiac function by increasing $\pm \mathrm{LV} \mathrm{dp} / \mathrm{dtmax}$, LVESP and limiting the increase of LVEDP in the rats with MI/R-induced injury. Similar to our study, Timmers et al observed that exenatide treatment improved cardiac function in a porcine model of MI/R-induced injury (12). These results strongly indicate that exenatide attenuates myocardial injury induced by oxidative stress.

A number of studies have confirmed that cardiomyocyte apoptosis is one of the most common pathophysiological processes in injury induced by oxidative stress and MI/R (3). Consistent with these reports, we demonstrated significantly higher cell apoptosis in $\mathrm{H}_{2} \mathrm{O}_{2}$-treated $\mathrm{H} 9 \mathrm{c} 2$ cells and in the rats with MI/R-induced injury. Furthermore, the anti-apoptotic effects of exenatide were confirmed by the results of Annexin V-FITC and TUNEL staining. These results strongly indicate that exenatide inhibits cell apoptosis induced by oxidative stress-induced injury.

On the basis of the obtained results that exenatide inhibits cardiomyocyte apoptosis induced by oxidative stress, we further investigated the possible mechanisms behind the anti-apoptotic effects of exenatide. Previous studies have demonstrated that the activation of the reperfusion injury salvage kinase (RISK) pathway, including PI3K/Akt and ERK $1 / 2$ provides an amenable pharmacological target for cardioprotection (29). Therefore, we speculate that the anti-apoptotic effects of exenatide may be responsible for the activation of the PI3K/Akt pathway. Accumulating evidence has shown that the PI3K/Akt signaling pathway can be activated by the phosphorylation of Akt to protect the myocardium from apoptosis following MI/R (30-32). The mechanisms behind the anti-apoptotic effects of PI3K/Akt signaling pathways are varied, such as inhibiting caspase activation, affecting glucose metabolism, regulating Bcl-2 family activity and inhibiting death gene expression. In the present study, we found that LY294002 (a specific inhibitor 
of PI3K) inhibits the functions of downstream target kinases of PI3K) and reverses the anti-apoptotic effects of exenatide, suggesting that the anti-apoptotic effects of exenatide are dependent on the PI3K/Akt pathway. More importantly, our data demonstrated that exenatide upregulated $\mathrm{Akt}^{\text {serine } 473}$ and Bad $^{\text {serine136 }}$ phosphorylation levels in $\mathrm{H}_{2} \mathrm{O}_{2}$-treated $\mathrm{H} 9 \mathrm{c} 2$ cells and in the rats with MI/R-induced injury, which in turn led to the decreased expression of cleaved caspase-3. However, these effects of exenatide were attenuated in the presence of LY294002. These results indicate that the anti-apoptotic effects of exenatide may be, at least in part, associated with the activation of the PI3K/Akt signaling pathway.

In conclusion, the prominent finding of this study was that exenatide exerts significant cardioprotective effects against oxidative stress induced by $\mathrm{H}_{2} \mathrm{O}_{2}$ and $\mathrm{MI} / \mathrm{R}$. The mechanisms involved may be attributed to the scavenging of oxidative stress products, increasing the concentration of antioxidant defense enzymes and inhibiting cardiomyocyte apoptosis. Moreover, the anti-apoptotic effects of exenatide are, at least in part, associated with the activation of the PI3K/Akt signaling pathway. The data from our study may provide a new and deeper insight into the therapeutic targets for ischemic heart disease.

\section{Acknowledgements}

This study was supported by the National Natural Science Funds for Youths (grant no. 81100196). We are grateful to Jianyong $\mathrm{Wu}$ and Dezhang Zhao (Institute of Life Sciences, Chongqing Medical University) for providing excellent technical support for the flow cytometry analysis.

\section{References}

1. Acar E, Ural D, Bildirici U, Sahin T and Yilmaz I: Diabetic cardiomyopathy. Anadolu Kardiyol Derg 11: 732-737, 2011.

2. Zweier JL and Talukder MA:The role of oxidants and free radicals in reperfusion injury. Cardiovasc Res 70: 181-190, 2006.

3. Zhao ZQ: Oxidative stress-elicited myocardial apoptosis during reperfusion. Curr Opin Pharmacol 4: 159-165, 2004.

4. Gottlieb RA: Cell death pathways in acute ischemia/reperfusion injury. J Cardiovasc Pharmacol Ther 16: 233-238, 2011.

5. Kajstura J, Cheng W, Reiss K, Clark WA, Sonnenblick EH, Krajewski S, Reed JC, Olivetti G and Anversa P: Apoptotic and necrotic myocyte cell deaths are independent contributing variables of infarct size in rats. Lab Invest 74: 86-107, 1996.

6. Palojoki E, Saraste A, Eriksson A, Pulkki K, Kallajoki M, Voipio-Pulkki LM and Tikkanen I: Cardiomyocyte apoptosis and ventricular remodeling after myocardial infarction in rats. Am J Physiol Heart Circ Physiol 280: H2726-H2731, 2001.

7. Garber AJ: Novel GLP-1 receptor agonists for diabetes. Expert Opin Investig Drugs 21: 45-57, 2012.

8. Davidson JA: Advances in therapy for type 2 diabetes: GLP-1 receptor agonists and DPP-4 inhibitors. Cleve Clin J Med 76 (Suppl 5): S28-S38, 2009.

9. Lorber D: GLP-1 receptor agonists: effects on cardiovascular risk reduction. Cardiovasc Ther: Jul 30, 2012 (Epub ahead of print).

10. Mundil D, Cameron-Vendrig A and Husain M: GLP-1 receptor agonists: a clinical perspective on cardiovascular effects. Diab Vasc Dis Res 9: 95-108, 2012.

11. Chiquette E, Toth PP, Ramirez G, Cobble M and Chilton R: Treatment with exenatide once weekly or twice daily for 30 weeks is associated with changes in several cardiovascular risk markers. Vasc Health Risk Manag 8: 621-629, 2012.

12. Timmers L, Henriques JP, de Kleijn DP, Devries JH, Kemperman H, Steendijk P, Verlaan CW, Kerver M, Piek JJ, Doevendans PA, Pasterkamp G and Hoefer IE: Exenatide reduces infarct size and improves cardiac function in a porcine model of ischemia and reperfusion injury. J Am Coll Cardiol 53: 501-510, 2009.
13. Laviola L, Leonardini A, Melchiorre M, Orlando MR, Peschechera A, Bortone A, Paparella D, Natalicchio A, Perrini S and Giorgino F: Glucagon-like peptide-1 counteracts oxidative stress-dependent apoptosis of human cardiac progenitor cells by inhibiting the activation of the c-Jun N-terminal protein kinase signaling pathway. Endocrinology 153: 5770-5781, 2012.

14. Ravassa S, Zudaire A, Carr RD and Díez J: Antiapoptotic effects of GLP-1 in murine HL-1 cardiomyocytes. Am J Physiol Heart Circ Physiol 300: H1361-H372, 2011.

15. Younce CW, Burmeister MA and Ayala JE: Exendin- 4 attenuates high glucose-induced cardiomyocyte apoptosis via inhibition of endoplasmic reticulum stress and activation of SERCA2a. Am J Physiol Cell Physiol 304: C508-C518, 2013.

16. Kumar S, Kain V and Sitasawad SL: High glucose-induced $\mathrm{Ca}^{2+}$ overload and oxidative stress contribute to apoptosis of cardiac cells through mitochondrial dependent and independent pathways. Biochim Biophys Acta 1820: 907-920, 2012.

17. Fishbein MC, Meerbaum S, Rit J, Lando U, Kanmatsuse K, Mercier JC, Corday E and Ganz W: Early phase acute myocardial infarct size quantification: validation of the triphenyl tetrazolium chloride tissue enzyme staining technique. Am Heart J 101:593-600, 1981.

18. Loesser KE, Kukreja RC, Kazziha SY, Jesse RL and Hess ML: Oxidative damage to the myocardium: a fundamental mechanism of myocardial injury. Cardioscience 2: 199-216, 1991.

19. Suzuki K, Murtuza B, Sammut IA, Latif N et al: Heat shock protein 72 enhances manganese superoxide dismutase activity during myocardial ischemia-reperfusion injury, associated with mitochondrial protection and apoptosis reduction. Circulation 106: I270-I276, 2002.

20. Peng $\mathrm{X}$ and Li Y: Induction of cellular glutathione-linked enzymes and catalase by the unique chemoprotective agent, $3 \mathrm{H}$-1,2-dithiole-3-thione in rat cardiomyocytes affords protection against oxidative cell injury. Pharmacol Res 45: 491-497, 2002.

21. Li C, Liu Z, Tian J, Li G, Jiang W, Zhang G, Chen F, Lin P and Ye Z: Protective roles of Asperosaponin VI, a triterpenesaponin isolated from Dipsacusasper Wall on acute myocardial infarction in rats. Eur J Pharmacol 627: 235-241, 2010.

22. Li J, Shao ZH, Xie JT, Wang CZ, Ramachandran S, Yin JJ, Aung H, Li CQ, Qin G, Vanden Hoek T and Yuan CS: The effects of ginsenoside Rb1 on JNK in oxidative injury in cardiomyocytes. Arch Pharm Res 35: 1259-1267, 2012.

23. Jin HB, Yang YB, Song YL, Zhang YC and Li YR: Protective roles of quercetin in acute myocardial ischemia and reperfusion injury in rats. Mol Biol Rep 39: 11005-11009, 2012.

24. Cai Y, Hu X, Yi B, Zhang T and Wen Z: Glucagon-like peptide-1 receptor agonist protects against hyperglycemia-induced cardiocytes injury by inhibiting high mobility group box 1 expression. Mol Biol Rep 39: 10705-10711, 2012.

25. Fontes JP, Gonçalves M and Ribeiro VG: Serum markers for ischemic myocardial damage. Rev Port Cardiol 18: 1129-1136,1999 (Portuguese).

26. Xie Y, Wang SX, Sha WW, Zhou X, Wang WL, Han LP, Li DQ and Yu DM: Effects and mechanism of glucagon-like peptide-1 on injury of rats cardiomyocytes induced by hypoxia-reoxygenation. Clin Med J 121: 2134-2138, 2008.

27. Chinda K, Chattipakorn S and Chattipakorn N: Cardioprotective effects of incretin during ischaemia-reperfusion. Diab Vasc Dis Res 9: 256-269, 2012.

28. Khalil PN, Neuhof C, Huss R, Pollhammer M, Khalil MN, Neuhof H, Fritz $\mathrm{H}$ and Siebeck M: Calpain inhibition reduces infarct size and improves global hemodynamics and left ventricular contractility in a porcine myocardial ischemia/reperfusion model. Eur J Pharmacol 528:124-131, 2005.

29. Hausenloy DJ and Yellon DM: New directions for protecting the heart against ischaemia-reperfusion injury: targeting the reperfusion injury s alvage kinase (RISK)-pathway. Cardiovasc Res 61: 448-460, 2004.

30. Mullonkal CJ and Toledo-Pereyra LH: Akt in ischemia and reperfusion. J Invest Surg 20: 195-203, 2007.

31. Fujio Y, Nguyen T, Wencker D, Kitsis RN and Walsh K: Akt promotes survival of cardiomyocytes in vitro and protects against ischemia-reperfusion injury in mouse heart. Circulation 101: 660-667, 2000.

32. Matsui T, Tao J, del Monte F, Lee KH, Li L, Picard M, Force TL, Franke TF, Hajjar RJ and Rosenzweig A: Akt activation preserves cardiac function and prevents injury after transient cardiac ischemia in vivo. Circulation 104: 330-335, 2001. 